\title{
Soil genesis and iron nodules in a karst environment of the Apodi Plateau $^{1}$
}

\author{
Gênese de solos e nódulos de ferro em ambiente cárstico na Chapada do Apodi
}

\author{
Rodrigo de Oliveira Girão²*, Leo Jakson da Silva Moreira ${ }^{3}$, Ana Leônia de Araújo Girão², Ricardo Espíndola \\ Romero $^{2}$ e Tiago Osório Ferreira ${ }^{4}$
}

\begin{abstract}
The Apodi Plateau, located in the northeastern part of the state of Ceará in Brazil, has limestone as its parent material, with significant variation in the soils formed in this region, as well as the presence of iron nodules, having been identified. The iron oxides have been used as indicators for evaluating the weathering processes of some soils, with the nodules being sources of information about pedogenic processes. Seeking to evaluate the influence of the karstic parent material and of the iron nodules on soil genesis in the Apodi Plateau, the morphological, physical and chemical properties of five profiles were evaluated, as well as of the iron nodules present in some horizons. The profiles were classified as RED-YELLOW ARGISOL Abruptic eutrophic plinthosol (P1), Tb HAPLIC CAMBISOL Eutrophic latosol (P2), RED-YELLOW ARGISOL Abruptic eutrophic plinthosol (P3), Tb HAPLIC CAMBISOL Eutrophic latosol (P4) and RED ARGISOL Eutrophic nitosol (P5). Changes in chemical, physical and morphological characteristics were observed at depth in some profiles, suggesting variation in the characteristics of the parent material. Nodules of class $\mathrm{C} 1$ (0.053 to $0.25 \mathrm{~mm}$ ) and C2 (0.25 to $2.00 \mathrm{~mm})$ were concentrated on the surface, alternating with a sub-surface concentration of class C3 (2.00 to $4.76 \mathrm{~mm}$ ), C4 (4.76 to $7.90 \mathrm{~mm}$ ) and C5 (7.90 to $19.1 \mathrm{~mm}$ ). Profile P5, considered as more evolved, showed a predominance of classes C1, C2 and C3 in the surface horizons, indicating degradation of the larger-diameter nodules with the advancing weathering process.
\end{abstract}

Key words: Pedogenic processes. Limestone. Soil classification.

RESUMO - A Chapada do Apodi, localizada na porção nordeste do Ceará, possui o calcário como material de origem e tem-se identificado relevante variação nos solos formados nessa região, bem como a presença de nódulos de ferro. Os óxidos de ferro têm sido usados como indicadores para avaliação dos processos de intemperismo de alguns solos, e esses nódulos são fontes de informações sobre processos pedogenéticos. Buscando avaliar a influência do material de origem cárstico e dos nódulos de ferro na gênese dos solos da Chapada do Apodi, foram avaliadas as propriedades morfológicas, físicas, e químicas de cinco perfis, bem como de nódulos de ferro presentes em alguns horizontes. Os perfis foram classificados como ARGISSOLO VERMELHO-AMARELO Eutrófico abrúptico plintossólicos (P1), CAMBISSOLO HÁPLICO Tb Eutrófico latossólico (P2), ARGISSOLO VERMELHO AMARELO Eutrófico abrúptico plintossólicos (P3), CAMBISSOLO HÁPLICO Tb Eutrófico latossólico (P4) e ARGISSOLO VERMELHO Eutrófico nitossólico (P5). Foram observadas alterações de características químicas, físicas e morfológicas em profundidade de alguns perfis, sugerindo uma variação nas características do material de origem. Os nódulos das classes C1 (0,053 - 0,25 mm) e C2 (0,25 - $2 \mathrm{~mm})$ concentraram-se superficialmente, alternando para uma concentração sub-superficial das classes C3 (2 - 4,76 mm), C4 (4,76 - 7,90 mm) e C5 (7,90 - 19,1 mm). O perfil considerado mais evoluído (P5) apresentou predomínio das classes C1, C2 e C3 nos horizontes mais superficiais, indicando degradação dos nódulos de maior diâmetro com o avançar do processo de intemperismo.

Palavras-chave: Processos pedogenéticos. Calcário. Classificação de solos.

\footnotetext{
*Autor para correspondência

${ }^{1}$ Recebido para publicação em 28/08/2013; aprovado em 26/06/2014

Parte da Dissertação de Mestrado em Solos e Nutrição de Plantas apresentada à Universidade Federal do Ceará desenvolvida com recursos do projeto financiado pelo Banco do Nordeste, intitulado "Atributos dos Solos Relacionados às Condições Paleo-Climáticas da Chapada do Apodi-CE

${ }^{2}$ Departamento de Ciências do Solo, Universidade Federal do Ceará/UFC, Campus do Pici, Av. Mister Hull, 2977, Bloco 807, Campus do Pici, Fortaleza-CE, Brasil,60.021-970,rogirao@gmail.com, analeonia@yahoo.com.br, reromero@ufc.br

${ }^{3}$ Departamento de Solos, Universidade Federal de Viçosa/UFV, Campus UFV, Viçosa-MG, Brasil, 36.570-000, leopontocom2004@ hotmail.com

${ }^{4}$ Departamento de Ciência do Solo, Escola Superior de Agricultura Luiz de Queiroz/ESALQ, Universidade de São Paulo, Avenida Pádua Dias, 11,

Vila Independência, Piracicaba-SP, Brasil, toferreira@ usp.br
} 


\section{INTRODUCTION}

Iron oxides can be used as pedogenic indicators as they make possible a better understanding of the evolution of the processes of weathering, being sensitive to variations in the environment, mainly to changes in the redox conditions of the soil, and so allow us to infer changes in the past forms of landscapes (COELHO; VIDAL-TORRADO, 2003; INDA-JUNIOR; KÄMPF, 2003).

The segregation and accumulation of iron can take place in many ways, being generally related to mottling, nodules, concretions and petroplinthite, among other classifications (CONSTANTINI; PRIORI, 2007). The formation of iron accumulated through nodules is influenced by seasonal variations in the water table (TAN et al., 2006), where materials having diffuse internal structures are formed by the continuous supply of iron. These materials can provide information about very common pedogenic processes in the soils of tropical and subtropical regions (CONSTANTINI et al., 2006; HUANG et al., 2008).

Colour is an important aspect of soils derived from limestone, and is used as one of the defining elements of the classification 'Terra rossa', employed for soils which have their origins in calcareous materials, with a clayey texture and reddish colours of varying hues ranging from $5 \mathrm{YR}$ to $10 \mathrm{R}$, and which are found in the Mediterranean region (AYDINALP; FITZPATRICK, 2009), being related to soils influenced by such iron oxides as hematite or goethite. Soils with similar characteristics, developed in other areas and also originating from calcareous materials have been documented, however under semi-arid climates (KHORMALI et al., 2003).

In Brazil, studies can be found related to soils which developed on calcareous materials with an occurrence of iron oxides; these generally being clayey soils of a reddish colour (5YR) and of oxide mineralogy (hematite and goethite), kaolinitic and micaceous. Lynch (2009) found Chernosols, Nitosols and Latosols in the Planaltina region of the state of Goiás. Oliveira et al. (2000) analysed Cambisols, Red Argisols and Red Latosols developed on limestone in the north of the state of Minas Gerais, and highlighted the presence of nodules and concretions of iron-manganese in the Cambisol profile. Pereira et al. (2013) carried out evaluations on the Serra da Bodoquena, in Mato Grosso do Sul, finding Organosols, Chernosols and Gleysols. Running further evaluations on the same region of Mato Grosso do Sul, Silva et al. (2013) found Red Argisols and Haplic Cambisols and stressed polygenesis as having strongly influencing this variation.

The Apodi plateau, located in the northeast of the state of Ceará in Brazil, is a fruit-producing region of importance in the state, and in soil surveys carried out in the 70s, large areas of Cambisols (BRASIL, 1973) were identified. Some more recent studies carried out in the region however, have shown variations in soil class and the presence of iron nodules (ALENCAR, 2002; MOTA et al., 2007), albeit with few detailed evaluations as to what factors may be contributing to these changes. Thus, with the aim of assessing the influence of the source material and of the iron nodules on the genesis of soils of the Apodi Plateau, morphological, chemical and physical analyses were carried out in five profiles formed from limestone.

\section{MATERIAL AND METHODS}

\section{Area under study}

The Apodi Plateau is inserted in the Potiguar Basin and is part of the Rift System of the Brazilian northeast. The emerged part of the Potiguar Basin displays the Acu and Jandaíra rock formations, the first consisting of red and green, clayey, micaceous and kaolinitic fine-grained sandstones and of siltstones of mostly fluvial origin, while the Jandaíra formation is characterised by the presence of calcite and dolomite, fine to medium grain limestones, which may be inter-bedded with cross-stratified sandy horizons (BRASIL, 1981; MOTA et al., 2008).

The area under study is of approximately 10 ha, planted with banana, and located in the town of Limoeiro do Norte, Ceará. The climate in the region according to the Köppen classification is BSw'h' (hot and semiarid), with an average annual temperature and precipitation of $28.5{ }^{\circ} \mathrm{C}$ and $772 \mathrm{~mm}$ respectively. The dominant topography of the region is flat, with a declivity ranging from 0.005 to $0.015 \mathrm{~m}^{-1}$ and an approximate elevation of $150 \mathrm{~m}$.

\section{Sampling and Analysis}

A transect of approximately 300 metres was established, where five trenches were opened (Figure 1), described and collected as per Santos et al. (2005). The area is of flat terrain with a declivity of around $0.01 \mathrm{~m}^{-1}$, the typical vegetation is hyper-xerophilic caatinga, and the small distances between profiles do not suggest variations in the climate. Samples from each horizon were broken up and passed through a $2 \mathrm{~mm}$ sieve in order to obtain fine, air-dried soil (FADS), in accordance with Empresa Brasileira de Pesquisa Agropecuária (1997). The soil profiles were classified according to Empresa Brasileira de Pesquisa Agropecuária (2013).

Granulometric composition was determined by the pipette method. The $\mathrm{pH}$ was determined in water and in a $1 \mathrm{~mol} \mathrm{~L}^{-1} \mathrm{KCl}$ solution in the ratio of $1: 2.5$. The organic carbon was obtained using the method proposed by Yeomans and Bremner (1988). The $\mathrm{Ca}^{2+}$ and $\mathrm{Mg}^{2+}$ cations and exchangeable acidity $\left(\mathrm{Al}^{3+}\right)$ were 
Figure 1 - Representation of profiles P1, P2, P3, P4 and P5, located in the area under study, the Apodi Plateau, Ceara, Brazil
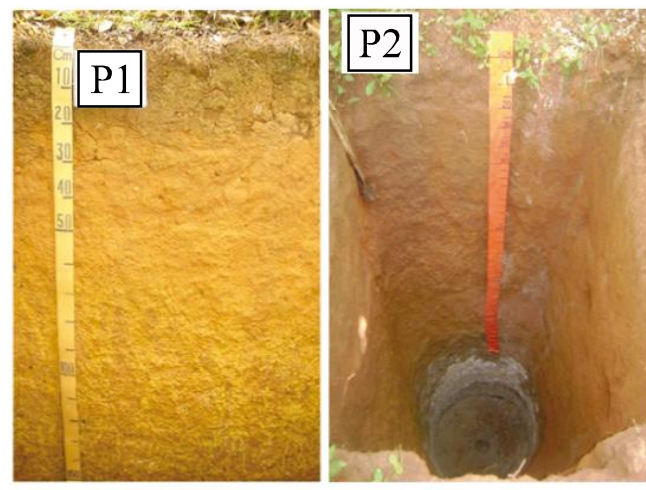
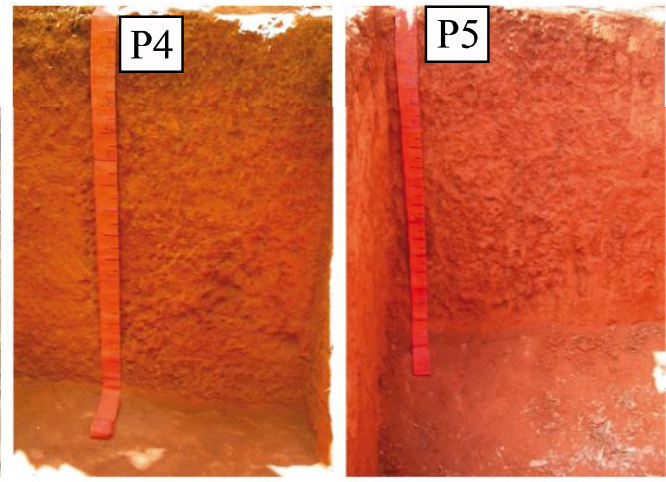

extracted with a $1 \mathrm{~mol} \mathrm{~L}^{-1} \mathrm{KCl}$ solution and determined by titration. The exchangeable $\mathrm{Na}^{+}$and $\mathrm{K}^{+}$were analysed by photometric method in a soil extract obtained with a Mehlich-1 solution. The potential acidity was determined by the volumetric method, with extraction by $0.5 \mathrm{~mol} \mathrm{~L}^{-1}$ calcium acetate at a $\mathrm{pH}$ of 7.0.

The levels of $\mathrm{Fe}$ in the fine-soil fraction were determined by atomic-absorption spectrophotometry after extraction with a solution of sodium dithionitecitrate-bicarbonate (DCB), in accordance with Mehra and Jackson (1960), and with Tamm's solution in the absence of light, according to Urley and Drees (2008). From the Fe content, extracted by ammonium oxalate $\left(\mathrm{Fe}_{\mathrm{o}}\right)$ and dithionite-citrate-bicarbonate $\left(\mathrm{Fe}_{\mathrm{d}}\right)$, the $\mathrm{Fe}_{\mathrm{o}} / \mathrm{Fe}_{\mathrm{d}}$ and $\mathrm{Fe}_{\mathrm{d}}$ /clay ratios were calculated, and used as a qualitative index of the degree of crystallinity of the oxides (INDA-JUNIOR, KÄMPF, 2005).

Using methodology proposed by Empresa Brasileira de Pesquisa Agropecuária (1997), the values for $\mathrm{SiO} 2, \mathrm{Fe}_{2} \mathrm{O}_{3}, \mathrm{Al}_{2} \mathrm{O}_{3}, \mathrm{MnO}_{2}$ and $\mathrm{TiO}_{2}$ were quantified by inductively coupled plasma optical emission spectroscopy (ICP OES).

\section{Iron Nodules}

The nodules of iron present in some horizons were separated from the soil matrix with the use of water-jet sieves and were then grouped into five diameter classes (C1 - 0.053 to $0.25, \mathrm{C} 2-0.25$ to $2.00, \mathrm{C} 3-2.00$ to 4.76 , C4 -4.76 to 7.90 and C5 -7.9 to $19.10 \mathrm{~mm}$ ).

After separation of the nodules the relative mass, density of the nodules was determined by the volumetric flask method (EMPRESA BRASILEIRA DE PESQUISA AGROPECUÁRIA, 1997) together with the levels of iron extracted by the ammonium oxalate $\left(\mathrm{Fe}_{\mathrm{o}}\right)$ and dithionite-citrate-bicarbonate $\left(\mathrm{Fe}_{\mathrm{d}}\right)$ (MEHRA; JACKSON, 1960; URLEY; DREES, 2008).

\section{RESULTS AND DISCUSSION}

\section{Genesis and Morphology}

The soils have depths exceeding $150 \mathrm{~cm}$ and display well-developed $\mathrm{A}$ and $\mathrm{B}$ horizons, thus indicating an evolving pedogenesis; with the exception of profile P3 there was no contact with the parent material of these soils. In general, the soils are of red and reddish colourations, indicating the presence of iron oxides, mainly hematite.

The soils of the Apodi Plateau were generally classified as Cambisols (BRASIL, 1973). However, on the transect defined in the study area, two profiles were classified as Cambisols, two soils identified as red-yellow Argisols and one as a red Argisol. Given the negligible changes in the other factors of formation, this would suggest that changes in source material are influencing this variability, also been reported by other authors (ACHURRA et al., 2009; ALENCAR, 2002; MOTA et al., 2007).

The occurrence of variations in limestone rocks reported by Bautista et al. (2011), where different layers may vary from centimetres to a few metres, can be considered as a cause of the variation seen in profile depth, such as in profile $\mathrm{P} 2(4.3+\mathrm{m})$ and profile $\mathrm{P} 3$ $(1.9 \mathrm{~m})$ (Table 1$)$, separated by a distance of $70 \mathrm{~m}$.

The prevailing hue of the profiles was $2.5 \mathrm{YR}$ (red) (Table 1). These reddish colours in soils developed on a karst environment are strongly related to a rapid precipitation of iron oxides due to the high $\mathrm{pH}$, which among other factors, favours the precipitation of ferrihydrate, a precursor of hematite, instead of goethite (SILVA NETO et al., 2008; TARDY; NAHON, 1985).

In profiles $\mathrm{P} 2$ and $\mathrm{P} 3$, vertic horizons were described just below the horizons that showed a greater accumulation of concretions (Table 1). Yaalon (2009) 
characterises vertic features as common in the lower parts of the landscape, due to the lateral and surface flow of solutions rich in $\mathrm{Ca}^{2+}$ and $\mathrm{Mg}^{2+}$, which favours the formation of $2: 1$ clays. The position of vertic horizons may be related to obstruction of the vertical flow of the soil solution resulting in the formation of such types of clay, further complemented by the alternating conditions of intense rainfall and prolonged dry periods which is characteristic of this environment, as reported by Anjos et al. (2007).

Table 1 - Morphological and physical characteristics of profiles P1, P2, P3, P4 and P5

\begin{tabular}{|c|c|c|c|c|c|c|c|}
\hline \multirow{2}{*}{ Hor } & \multirow{2}{*}{$\frac{\text { Depth }}{\mathrm{cm}}$} & \multicolumn{2}{|c|}{ Colour } & \multirow{2}{*}{ Structure } & \multirow[t]{2}{*}{ Sand } & \multirow{2}{*}{$\frac{\text { Silte }}{\mathrm{g} \mathrm{kg}^{-1}}$} & \multirow[t]{2}{*}{ Clay } \\
\hline & & Moist & Dry & & & & \\
\hline \multicolumn{8}{|c|}{ P1 - RED-YELLOW ARGISOL Abruptic eutrophic plintosol (PVAe) } \\
\hline $\mathrm{AP}$ & $0-13$ & 5YR 3/4 & $5 Y R 4 / 4$ & mod sm bl suba mod vry sm gra & 466 & 125 & 409 \\
\hline $\mathrm{AB}$ & $13-23$ & 2,5YR 3/4 & & mod lge vry lge bl ang & 454 & 116 & 430 \\
\hline Btc1 & $23-50$ & $2,5 \mathrm{YR} 4 / 6$ & & mod sm md bl suba & 220 & 142 & 638 \\
\hline Btcf2 & $50-70$ & $5 Y R 5 / 6$ & & mod sm md bl suba & 258 & 107 & 635 \\
\hline $\mathrm{B} / \mathrm{Ccf} 3$ & $70-103$ & $5 \mathrm{YR} 4 / 6$ & & mod vry sm bl suba & 299 & 168 & 533 \\
\hline $\mathrm{B} / \mathrm{Cf}$ & $103-153+$ & $5 Y R 4 / 6$ & & mod sm bl ang suba & 532 & 122 & 346 \\
\hline \multicolumn{8}{|c|}{ P2 - HAPLIC CAMBISOL Tb Eutrophic latosol (CXbe) } \\
\hline Apc1 & $0-18$ & 5YR 3/4 & $5 \mathrm{YR} 4 / 6$ & mod md bl suba & 540 & 177 & 283 \\
\hline Ac2 & $18-37$ & $5 \mathrm{YR} 4 / 4$ & 5YR 5/6 & mod md lge bl suba & 561 & 115 & 324 \\
\hline Bic1 & $37-60$ & $5 Y R 4 / 6$ & 5YR 5/8 & mod md bl suba & 269 & 181 & 450 \\
\hline Bic2 & $60-95$ & $5 Y R 4 / 6$ & $5 Y R 6 / 8$ & mod md bl suba & 356 & 206 & 438 \\
\hline $\mathrm{Bi} 3$ & $95-166$ & 5YR 4,5/8 & $5 Y R 6 / 8$ & mod md bl suba & 337 & 220 & 443 \\
\hline Bicf4 & $166-180$ & 10YR 7/8 & 7,5YR 6/8 & mod md lge bl ang suba & 309 & 268 & 423 \\
\hline Bicf5 & $180-253$ & 10YR 6/8 & 10YR 8/8 & mod md lge bl ang suba & 352 & 217 & 431 \\
\hline Cv1 & $253-285$ & 10YR 5/6 & 10YR 6/6 & str lge pris & 190 & 232 & 578 \\
\hline $\mathrm{Cr} 2$ & $285-335$ & 10YR 8/1 & 10YR 8/1 & & 158 & 716 & 126 \\
\hline $\mathrm{Cr} 3$ & $335-430+$ & 10YR 7/5 & 10YR 7/1 & & 342 & 471 & 187 \\
\hline \multicolumn{8}{|c|}{ P3 - RED-YELLOW ARGISOL Abrupt eutrophic plintosol (PVAe) } \\
\hline AP & $0-29$ & 7,5YR 4/3 & $7,5 \mathrm{YR} 4 / 5$ & str lge bl suba & 460 & 190 & 350 \\
\hline Bt1 & $29-51$ & 2,5YR 4/7 & 7,5YR 5/8 & str md lge bl suba & 310 & 120 & 570 \\
\hline $\mathrm{Bt} 2$ & $51-86$ & $5 \mathrm{YR} 4 / 6$ & $5 \mathrm{YR} 5 / 8$ & mod md lge bl suba & 300 & 170 & 530 \\
\hline $\mathrm{Bt} 3$ & $86-110$ & 5YR 5/8 & 5YR 5/8 & mod md lge bl suba & 300 & 140 & 560 \\
\hline Btc4 & $110-140$ & 10YR 6/8 & 10YR 7/8 & & 260 & 210 & 530 \\
\hline Cv1 & $140-160$ & 10YR 5/8 & 10YR 6/8 & str md lge pris bl ang & 220 & 160 & 620 \\
\hline $\mathrm{Cr} 2$ & $160-190$ & & & & 306 & 457 & 237 \\
\hline \multicolumn{8}{|c|}{ P4 - HAPLIC CAMBISOL Tb Eutrophic latosol (CXbe) } \\
\hline $\mathrm{AP}$ & $0-31$ & $5 Y R 3 / 4$ & $5 \mathrm{YR} 4 / 6$ & mod md lge bl suba & 450 & 170 & 380 \\
\hline BA & $31-54$ & 2,5YR 4/6 & 5YR 5/8 & mod md lge bl suba & 330 & 150 & 520 \\
\hline Bi1 & $54-93$ & $2,5 \mathrm{YR} 4 / 6$ & 5YR 5/7 & mod md bl suba & 240 & 160 & 600 \\
\hline $\mathrm{Bi} 2$ & $93-135$ & $2,5 \mathrm{YR} 4,5 / 8$ & 5YR 6/8 & mod md bl suba & 290 & 130 & 580 \\
\hline $\mathrm{Bi} 3$ & $135-162+$ & 5YR 4,5/6 & 7,5YR 5/8 & mod md bl suba & 280 & 190 & 530 \\
\hline
\end{tabular}


Table 1 continued

\begin{tabular}{|c|c|c|c|c|c|c|c|}
\hline \multicolumn{8}{|c|}{ P5 - RED ARGISOL Eutrophic nitosol (PVe) } \\
\hline $\mathrm{A}$ & $0-12$ & 10R 3/4 & $5 Y R 4 / 6$ & mod sm md lge bl suba & 428 & 140 & 432 \\
\hline BA & $12-44$ & $2,5 \mathrm{YR} 4 / 6$ & $2,5 \mathrm{YR} 4 / 8$ & mod md lge bl suba & 228 & 96 & 676 \\
\hline B1 & $44-75$ & 2,5YR 4/7 & 2,5 YR $5 / 8$ & mod md bl suba & 212 & 89 & 699 \\
\hline B2 & $75-124$ & $2,5 \mathrm{YR} 4 / 8$ & 2,5 YR $5 / 7$ & mod md lge bl ang suba & 269 & 130 & 601 \\
\hline B3 & $124-170+$ & $2,5 \mathrm{YR} 4 / 8$ & $2,5 Y R 5 / 8$ & mod md lge bl ang suba & 363 & 105 & 532 \\
\hline
\end{tabular}

\section{Chemistry and physics}

All of the profiles displayed high values for $\mathrm{V} \%$ (Table 2), a fact also noted by Foster, Chittleborough and Barovich (2004), who found high CEC in soils identified as "Terra rossa', especially for $\mathrm{Ca}^{2+}$, to which is attributed the ability for particle aggregation.

The texture of the profiles is predominantly clayey and very clayey, reaching values of the order of $700 \mathrm{~g} \mathrm{~kg}^{-1}$ in profile P5 (Table 1). Moreover, the texture gradient present in profiles $\mathrm{P} 1, \mathrm{P} 3$ and $\mathrm{P} 5$, and the significant amount of waxiness in the last profile are evidence of clay illuviation, a feature also identified by Delgado et al. (2003) as one of the determining factors in the genesis of soils on karst environments in Spain.

The values for the $\mathrm{CaCO}_{3}$ found were low, with the hypo-carbonate feature (EMPRESA BRASILEIRA DE PESQUISA AGROPECUÁRIA, 2013) only being identified in some of the deeper horizons of profiles P2 and P3 (Table 2). The reason for the low values may be due to better drainage in the profiles favouring solubilisation and leaching.

The Cr layers of profiles $\mathrm{P} 2$ and $\mathrm{P} 3$, materials which are still little weathered, look to be different material to that which gave rise to the overlying horizons, since they appeared strongly stratified, which may be related to wind deposition and a large selection of grains, as evidenced by the silt content (Table 1). Feng (2011), when evaluating insoluble residues of dolomitic limestones in China, found a predominance of fine materials, mainly sand and silt.

The $\mathrm{Cr} 2$ and $\mathrm{Cr} 3$ horizons of profile $\mathrm{P} 2$, and the $\mathrm{Cv} 1$ horizon of profile $\mathrm{P} 3$ showed an abrupt change in the values of the $\mathrm{Fe}_{\mathrm{o}} / \mathrm{Fe}_{\mathrm{d}}$ ratio (Table 3). As they represent the basal horizons of the profiles, this increase may be related to greater humidity or suggest strata variation in the source material.

In the $\mathrm{Cv} 1$ horizon of profile $\mathrm{P} 2$, and the $\mathrm{Cv} 1$ horizon of profile $\mathrm{P} 3$, there is a strong reduction in the amounts of iron extracted through sulphuric acid attack, and in the underlying horizons of the same profiles the reduction is even greater, together with a decrease in the values of silica, reinforcing the hypothesis of variation in the properties of the source material (Table 4).

The values for $\mathrm{TiO}_{2}$ in horizons $\mathrm{Cr} 2$ and $\mathrm{Cr} 3$ of profile $\mathrm{P} 2$, and $\mathrm{Cr} 2$ of profile $\mathrm{P} 3$ show a clear contrast (Table 4), as their values are of the order of $2 \mathrm{~g} \mathrm{~kg}-1$ in these horizons, while in the above horizons they are of the order of $6 \mathrm{~g} \mathrm{~kg}-1$, confirming the observations of JiménezMillán and Nieto (2008). Further, variation was observed in the values of $\mathrm{TiO}_{2}$ in the above profiles, from the surface to where horizons showing a presence of concretions were identified, suggesting that the source material from the surface to the concretions differs from the source material of the last layers of these profiles.

Among the studied profiles, the Ki index (Table 4), used to relate the weathering intensity, shows that P5 is the profile displaying the highest degree of pedogenetic evolution, this can be evidenced by the lower CEC of the profile. The $\mathrm{Kr}$ index greater than 0.75 indicates the presence of kaolinitic soils (MOTA et al., 2007).

\section{Iron nodules}

The occurrence and size of iron nodules differ for depth in the profiles under study (Figure 2). Nodules having smaller diameters, included in the sand fraction and belonging to classes $\mathrm{C} 1$ and $\mathrm{C} 2$ (Figure 2), tend to concentrate at the top of the profiles. The larger nodules, with a size equivalent to the gravel fraction (classes C3, C4 and C5), showed the highest values in horizons B and C. A similar condition was noted by Arocena, Pawluk and Dudas (1994) when evaluating nodules rich in iron in soils in Canada. Variations in such chemical conditions as oxidation / reduction, which are also influenced by such physical conditions as the wet and dry cycles, may have favoured this separation, as perhaps did the fragmentation caused by agricultural activities. 
Table 2 - Chemical characteristics of profiles P1, P2, P3, P4 and P5

\begin{tabular}{|c|c|c|c|c|c|c|c|c|c|c|c|c|c|}
\hline \multirow{2}{*}{ Hor } & \multirow{2}{*}{$\frac{\text { Depth }}{\mathrm{cm}}$} & \multicolumn{2}{|c|}{$\mathrm{pH}$} & \multirow{2}{*}{$\frac{\mathrm{OC}}{\mathrm{g} \mathrm{kg}^{-1}}$} & \multirow[t]{2}{*}{$\mathrm{Ca}^{2+}$} & \multirow[t]{2}{*}{$\mathrm{Mg}^{2+}$} & \multirow[t]{2}{*}{$\mathrm{K}^{+}$} & \multirow[t]{2}{*}{$\mathrm{Na}^{+}$} & \multirow[t]{2}{*}{$\mathrm{Al}^{3+}+\mathrm{H}^{+}$} & \multirow[t]{2}{*}{$\mathrm{S}$} & \multirow{2}{*}{$\begin{array}{c}\mathrm{T} \\
----\end{array}$} & \multirow{2}{*}{$\frac{\mathrm{V}}{\%}$} & \multirow{2}{*}{$\frac{\mathrm{CaCO} 3}{\mathrm{~g} \mathrm{~kg}^{-1}}$} \\
\hline & & $\mathrm{H}_{2} \mathrm{O}$ & $\mathrm{KCl}$ & & & & & & & & & & \\
\hline \multicolumn{14}{|c|}{ P1 - RED-YELLOW ARGISOL Abrupt eutrophic plintosol (PVAe) } \\
\hline AP & $0-13$ & 8.0 & 7.1 & 10.00 & 6.8 & 3.3 & 1.1 & 0.4 & 0.0 & 11.7 & 11.7 & 100 & 38 \\
\hline $\mathrm{AB}$ & $13-23$ & 7.6 & 6.7 & 7.10 & 6.2 & 2.7 & 0.9 & 0.8 & 0.0 & 10.7 & 10.7 & 100 & 33 \\
\hline Btc1 & $23-50$ & 7.2 & 6.1 & 2.50 & 6.5 & 3.1 & 0.3 & 0.8 & 0.0 & 10.8 & 10.8 & 100 & 36 \\
\hline Btcf2 & $50-70$ & 5.7 & 5.0 & 2.40 & 5.2 & 2.9 & 0.1 & 0.7 & 1.8 & 9.0 & 10.8 & 83 & 38 \\
\hline B/Ccf3 & $70-103$ & 5.4 & 5.0 & 1.60 & 4.3 & 3.3 & 0.1 & 0.6 & 1.5 & 8.4 & 9.9 & 85 & 37 \\
\hline $\mathrm{B} / \mathrm{Cf}$ & $103-153+$ & 5.7 & 5.1 & 1.00 & 3.0 & 3.4 & 0.1 & 0.8 & 1.0 & 7.3 & 8.3 & 88 & 38 \\
\hline \multicolumn{14}{|c|}{ P2 - HAPLIC CAMBISOL Tb Eutrophic latosol (CXbe) } \\
\hline Ap1 & $0-18$ & 7.6 & 6.6 & 13.68 & 3.1 & 2.1 & 0.7 & 0.1 & 0.0 & 6.0 & 6.1 & 98 & 30 \\
\hline A2 & $18-37$ & 7.6 & 6.4 & 7.69 & 2.4 & 2.6 & 0.3 & 0.1 & 0.0 & 5.5 & 5.6 & 98 & 33 \\
\hline Bi1 & $37-60$ & 7.6 & 6.3 & 6.34 & 2.5 & 1.3 & 0.2 & 0.1 & 0.0 & 4.2 & 4.4 & 96 & 31 \\
\hline $\mathrm{Bi} 2$ & $60-95$ & 7.0 & 5.9 & 5.65 & 2.6 & 0.9 & 0.1 & 0.2 & 0.0 & 3.8 & 3.9 & 98 & 36 \\
\hline $\mathrm{Bi} 3$ & $95-166$ & 5.6 & 4.5 & 2.81 & 1.5 & 2.0 & 0.1 & 0.3 & 1.2 & 3.9 & 5.1 & 77 & 43 \\
\hline Bicf4 & $166-180$ & 5.8 & 4.7 & 5.50 & 2.2 & 1.0 & 0.1 & 0.4 & 1.3 & 3.7 & 5.0 & 75 & 36 \\
\hline Bicf5 & $180-253$ & 5.9 & 4.9 & 4.06 & 1.6 & 2.8 & 0.1 & 0.2 & 1.1 & 4.8 & 6.0 & 81 & 35 \\
\hline Cv1 & $253-285$ & 7.3 & 5.9 & 3.56 & 7.5 & 10.2 & 0.2 & 0.5 & 0.1 & 18.5 & 18.6 & 99 & 52 \\
\hline $\mathrm{Cr} 2$ & $285-335$ & 8.8 & 7.9 & 1.84 & 3.0 & 2.7 & 0.1 & 0.1 & 0.0 & 6.1 & 6.1 & 100 & 149 \\
\hline $\mathrm{Cr} 3$ & $335-430+$ & 8.7 & 7.6 & 2.69 & 3.8 & 4.4 & 0.2 & 0.3 & 0.0 & 8.7 & 8.7 & 100 & 149 \\
\hline \multicolumn{14}{|c|}{ P3 - RED-YELLOW ARGISOL Abrupt eutrophic plintosol (PVAe) } \\
\hline $\mathrm{AP}$ & $0-29$ & 8.0 & 7.2 & 18.78 & 3.1 & 1.6 & 0.3 & 0.1 & 1.0 & 5.2 & 6.2 & 87 & 29 \\
\hline Bt1 & $29-51$ & 7.9 & 6.7 & 7.44 & 4.7 & 1.6 & 0.2 & 0.3 & 1.0 & 6.9 & 7.9 & 87 & 31 \\
\hline $\mathrm{Bt} 2$ & $51-86$ & 7.6 & 6.3 & 4.28 & 5.0 & 2.3 & 0.1 & 0.4 & 2.0 & 8.0 & 10.0 & 77 & 29 \\
\hline $\mathrm{Bt} 3$ & $86-110$ & 6.4 & 5.4 & 4.31 & 4.0 & 2.4 & 0.1 & 0.4 & 2.0 & 6.9 & 8.9 & 74 & 29 \\
\hline Btc4 & $110-140$ & 6.4 & 5.3 & 2.75 & 3.2 & 3.2 & 0.1 & 0.3 & 2.0 & 6.8 & 8.8 & 78 & 26 \\
\hline Cv1 & $140-160$ & 6.1 & 4.9 & 2.91 & 3.7 & 5.6 & 0.1 & 0.6 & 2.0 & 11 & 13.1 & 86 & 38 \\
\hline $\mathrm{Cr} 2$ & $160-190$ & 8.6 & 7.6 & 2.22 & 6.6 & 3.8 & 0.1 & 0.3 & 0.0 & 11 & 11 & 100 & 149 \\
\hline \multicolumn{14}{|c|}{ P4 - HAPLIC CAMBISOL Tb Eutrophic latosol (CXbe) } \\
\hline AP & $0-31$ & 7.7 & 6.8 & 14.31 & 5.4 & 2.4 & 0.3 & 0.1 & 0.0 & 8.2 & 8.2 & 100 & 10 \\
\hline BA & $31-54$ & 7.7 & 6.5 & 6.65 & 4.4 & 0.9 & 0.2 & 0.1 & 0.0 & 5.7 & 5.7 & 98 & 32 \\
\hline Bi1 & $54-93$ & 6.6 & 5.6 & 3.94 & 3.4 & 1.4 & 0.2 & 0.1 & 0.0 & 5.1 & 5.1 & 98 & 30 \\
\hline $\mathrm{Bi} 2$ & $93-135$ & 5.9 & 4.8 & 4.31 & 2.9 & 1.5 & 0.2 & 0.1 & 2.1 & 4.8 & 6.8 & 69 & 29 \\
\hline $\mathrm{Bi3}$ & $135-162+$ & 6.2 & 5.1 & 4.37 & 3.1 & 1.8 & 0.1 & 0.1 & 2.1 & 5.3 & 7.4 & 71 & 32 \\
\hline \multicolumn{14}{|c|}{ P5 - RED ARGISOL Eutrophic nitosol (PVe) } \\
\hline A & $0-12$ & 7.0 & 5.8 & 18.81 & 3.2 & 2.5 & 0.1 & 0.1 & 0.0 & 5.8 & 5.8 & 99 & 33 \\
\hline BA & $12-44$ & 7.7 & 6.1 & 8.25 & 3.1 & 1.7 & 0.1 & 0.1 & 0.0 & 5.0 & 5.1 & 98 & 33 \\
\hline B1 & $44-75$ & 6.1 & 4.9 & 5.56 & 2.1 & 1.8 & 0.1 & 0.1 & 1.0 & 4.0 & 5.1 & 79 & 30 \\
\hline B2 & $75-124$ & 5.2 & 4.6 & 4.19 & 1.8 & 2.2 & 0.1 & 0.1 & 2.1 & 4.1 & 6.2 & 66 & 28 \\
\hline B3 & $124-170+$ & 5.2 & 4.7 & 4.12 & 1.7 & 2.0 & 0.1 & 0.1 & 2.2 & 3.9 & 6.1 & 64 & 29 \\
\hline
\end{tabular}

Hor-Horizon; OC-organic carbon; S-sum of bases; T-cation exchange capacity; V-Base saturation 
Table 3 - Values for iron in sodium dithionite-citrate-bicarbonate $\left(\mathrm{Fe}_{\mathrm{d}}\right)$, iron in ammonium oxalate $\left(\mathrm{Fe}_{\mathrm{o}}\right)$, ratio of iron in the oxalate to iron in the dithionite $\left(\mathrm{Fe}_{\mathrm{o}} / \mathrm{Fe}_{\mathrm{d}}\right.$ ) and ratio of iron in the dithionite to clay ( $\mathrm{Fe}_{\mathrm{d}} / \mathrm{Clay}$ ) in profiles P1, P2, P3, P4 and P5

\begin{tabular}{|c|c|c|c|c|c|}
\hline \multirow{2}{*}{ Horizon } & Depth & Fed & Feo & \multirow{2}{*}{$\mathrm{Feo} / \mathrm{Fed}$} & \multirow{2}{*}{ Fed/Clay } \\
\hline & $\mathrm{cm}$ & ------------- & ----------- & & \\
\hline \multicolumn{6}{|c|}{ P1 - RED-YELLOW ARGISOL Abrupt eutrophic plintosol (PVAe) } \\
\hline $\mathrm{Ap}$ & $0-13$ & 20.41 & 2.58 & 0.13 & 0.05 \\
\hline $\mathrm{AB}$ & $13-23$ & 43.91 & 2.91 & 0.07 & 0.10 \\
\hline Btc1 & $23-50$ & 27.84 & 2.54 & 0.09 & 0.04 \\
\hline Btcf2 & $50-70$ & 26.34 & 1.92 & 0.07 & 0.04 \\
\hline $\mathrm{B} / \mathrm{Ccf} 3$ & $70-103$ & 22.79 & 1.59 & 0.07 & 0.04 \\
\hline $\mathrm{B} / \mathrm{Cf}$ & $103-153+$ & 22.34 & 1.63 & 0.07 & 0.06 \\
\hline \multicolumn{6}{|c|}{ P2 - HAPLIC CAMBISOL Tb Eutrophic latosol (CXbe) } \\
\hline Ap1 & $0-18$ & 28.24 & 2.23 & 0.08 & 0.10 \\
\hline A2 & $18-37$ & 29.57 & 2.28 & 0.08 & 0.09 \\
\hline Bi1 & $37-60$ & 29.28 & 2.72 & 0.09 & 0.07 \\
\hline $\mathrm{Bi} 2$ & $60-95$ & 23.48 & 1.71 & 0.07 & 0.05 \\
\hline Bi3 & $95-166$ & 26.62 & 1.08 & 0.04 & 0.06 \\
\hline Bicf4 & $166-180$ & 30.80 & 1.89 & 0.06 & 0.07 \\
\hline Bicf5 & $180-253$ & 31.95 & 1.80 & 0.06 & 0.07 \\
\hline Cv1 & $253-285$ & 17.16 & 1.73 & 0.10 & 0.03 \\
\hline $\mathrm{Cr} 2$ & $285-335$ & 2.59 & 0.39 & 0.15 & 0.02 \\
\hline $\mathrm{Cr} 3$ & $335-430+$ & 3.34 & 3.79 & 1.14 & 0.02 \\
\hline \multicolumn{6}{|c|}{ P3 - RED-YELLOW ARGISOL Abrupt eutrophic plintosol (PVAe) } \\
\hline $\mathrm{Ap}$ & $0-29$ & 20.27 & 2.39 & 0.12 & 0.06 \\
\hline Bt1 & $29-51$ & 18.87 & 2.72 & 0.14 & 0.03 \\
\hline $\mathrm{Bt} 2$ & $51-86$ & 18.00 & 2.25 & 0.13 & 0.03 \\
\hline $\mathrm{Bt} 3$ & $86-110$ & 27.40 & 1.82 & 0.07 & 0.05 \\
\hline Btc4 & $110-140$ & 35.29 & 2.88 & 0.08 & 0.07 \\
\hline Cv1 & $140-160$ & 20.66 & 4.35 & 0.21 & 0.03 \\
\hline $\mathrm{Cr} 2$ & $160-190$ & 10.36 & 0.79 & 0.08 & 0.04 \\
\hline \multicolumn{6}{|c|}{ P4 - HAPLIC CAMBISOL Tb Eutrophic latosol (CXbe) } \\
\hline Ap & $0-31$ & 38.88 & 2.67 & 0.07 & 0.10 \\
\hline BA & $31-54$ & 23.97 & 2.85 & 0.12 & 0.05 \\
\hline Bi1 & $54-93$ & 24.82 & 2.63 & 0.11 & 0.04 \\
\hline $\mathrm{Bi} 2$ & $93-135$ & 31.26 & 2.44 & 0.08 & 0.05 \\
\hline $\mathrm{Bi3}$ & $135-162+$ & 20.54 & 2.72 & 0.13 & 0.04 \\
\hline \multicolumn{6}{|c|}{ P5 - RED ARGISOL Eutrophic nitosol (PVe) } \\
\hline A & $0-12$ & 22.24 & 3.31 & 0.15 & 0.05 \\
\hline $\mathrm{BA}$ & $12-44$ & 17.84 & 2.80 & 0.16 & 0.03 \\
\hline B1 & $44-75$ & 26.12 & 1.85 & 0.07 & 0.04 \\
\hline B2 & $75-124$ & 20.84 & 2.32 & 0.11 & 0.03 \\
\hline B3 & $124-170+$ & 24.82 & 1.51 & 0.06 & 0.05 \\
\hline
\end{tabular}


Table 4 - Percentage of $\mathrm{SiO}_{2}, \mathrm{Fe}_{2} \mathrm{O}_{3}, \mathrm{Al}_{2} \mathrm{O}_{3}, \mathrm{MnO}_{2}$ and $\mathrm{TiO}_{2}$ and the molecular indices $\mathrm{Kr}$ and $\mathrm{Ki}$ determined in the extract from the sulphuric acid attack for profiles P1, P2, P3, P4 and P5

\begin{tabular}{|c|c|c|c|c|c|c|c|c|}
\hline \multirow{2}{*}{ Horizon } & Depth & $\mathrm{SiO}_{2}$ & $\mathrm{Fe}_{2} \mathrm{O}_{3}$ & $\mathrm{Al}_{2} \mathrm{O}_{3}$ & $\mathrm{MnO}_{2}$ & $\mathrm{TiO}_{2}$ & $\mathrm{Ki}$ & $\mathrm{Kr}$ \\
\hline & \multicolumn{8}{|c|}{ - } \\
\hline \multicolumn{9}{|c|}{ P1 - RED-YELLOW ARGISOL Abrupt eutrophic plintosol (PVAe) } \\
\hline Ap & $0-13$ & 164.0 & 73.8 & 151.3 & 0.57 & 5.20 & 1.84 & 1.41 \\
\hline $\mathrm{AB}$ & $13-23$ & 267.0 & 79.8 & 179.8 & 0.52 & 5.43 & 2.52 & 1.97 \\
\hline Btc1 & $23-50$ & 275.8 & 81.6 & 217.5 & 0.45 & 6.13 & 2.16 & 1.74 \\
\hline Btcf2 & $50-70$ & 310.7 & 83.5 & 224.4 & 0.71 & 6.37 & 2.35 & 1.90 \\
\hline $\mathrm{B} / \mathrm{Ccf} 3$ & $70-103$ & 242.0 & 80.5 & 202.1 & 0.35 & 6.45 & 2.04 & 1.62 \\
\hline $\mathrm{B} / \mathrm{Cf}$ & $103-153+$ & 268.5 & 75.6 & 191.4 & 0.41 & 5.65 & 2.38 & 1.90 \\
\hline \multicolumn{9}{|c|}{ P2 - HAPLIC CAMBISOL Tb Eutrophic latosol (CXbe) } \\
\hline Ap1 & $0-18$ & 155.4 & 79.7 & 146.7 & 0.94 & 5.18 & 1.80 & 1.34 \\
\hline $\mathrm{A} 2$ & $18-37$ & 161.3 & 86.6 & 153.1 & 0.93 & 5.28 & 1.79 & 1.32 \\
\hline Bi1 & $37-60$ & 223.5 & 79.4 & 186.3 & 0.64 & 6.54 & 2.04 & 1.60 \\
\hline $\mathrm{Bi} 2$ & $60-95$ & 207.2 & 88.2 & 196.4 & 0.64 & 7.05 & 1.79 & 1.39 \\
\hline $\mathrm{Bi} 3$ & $95-166$ & 260.5 & 68.9 & 171.7 & 0.39 & 6.03 & 2.58 & 2.05 \\
\hline Bicf4 & $166-180$ & 257.1 & 61.9 & 188.9 & 0.29 & 5.02 & 2.31 & 1.91 \\
\hline Bicf5 & $180-253$ & 271.6 & 99.6 & 220.4 & 0.44 & 6.42 & 2.10 & 1.63 \\
\hline Cv1 & 253-285 & 323.3 & 49.7 & 122.7 & 1.95 & 4.48 & 4.48 & 3.56 \\
\hline $\mathrm{Cr} 2$ & 285-335 & - & 10.1 & 28.2 & 0.27 & 1.33 & 0.00 & - \\
\hline $\mathrm{Cr} 3$ & $335-430+$ & 10.8 & 17.9 & 50.2 & 0.31 & 2.18 & 0.37 & 0.30 \\
\hline \multicolumn{9}{|c|}{ P3 - RED-YELLOW ARGISOL Abrupt eutrophic plintosol (PVAe) } \\
\hline Ap & $0-29$ & 184.5 & 67.9 & 137.6 & 0.81 & 5.28 & 2.28 & 1.73 \\
\hline Bt1 & $29-51$ & 214.1 & 80.9 & 173.5 & 0.69 & 6.17 & 2.10 & 1.62 \\
\hline $\mathrm{Bt} 2$ & $51-86$ & 261.4 & 86.7 & 187.8 & 0.46 & 6.22 & 2.37 & 1.83 \\
\hline $\mathrm{Bt} 3$ & $86-110$ & 278.1 & 86.0 & 195.9 & 0.37 & 6.01 & 2.41 & 1.89 \\
\hline Btc4 & $110-140$ & 268.5 & 97.8 & 207.5 & 0.91 & 6.25 & 2.20 & 1.69 \\
\hline Cv1 & $140-160$ & 290.4 & 88.0 & 203.9 & 0.89 & 7.26 & 2.42 & 1.90 \\
\hline $\mathrm{Cr} 2$ & $160-190$ & 7.0 & 15.3 & 43.0 & 0.15 & 1.81 & 0.28 & 0.22 \\
\hline \multicolumn{9}{|c|}{ P4 - HAPLIC CAMBISOL Tb Eutrophic latosol (CXbe) } \\
\hline Ap & $0-31$ & 182.5 & 72.1 & 145.4 & 0.92 & 5.02 & 2.13 & 1.62 \\
\hline $\mathrm{BA}$ & $31-54$ & 271.0 & 77.5 & 210.3 & 0.52 & 6.13 & 2.19 & 1.77 \\
\hline Bi1 & $54-93$ & 285.6 & 79.4 & 219.8 & 0.49 & 6.76 & 2.21 & 1.80 \\
\hline $\mathrm{Bi} 2$ & $93-135$ & 249.7 & 64.1 & 175.9 & 0.50 & 5.07 & 2.41 & 1.96 \\
\hline $\mathrm{Bi} 3$ & $135-162+$ & 266.4 & 71.8 & 195.2 & 0.44 & 5.39 & 2.32 & 1.88 \\
\hline \multicolumn{9}{|c|}{ P5 - RED ARGISOL Eutrophic nitosol (PVe) } \\
\hline $\mathrm{A}$ & $0-12$ & 187.4 & 87.8 & 179.9 & 1.04 & 6.37 & 1.77 & 1.35 \\
\hline $\mathrm{BA}$ & $12-44$ & 295.0 & 87.1 & 245.0 & 0.67 & 6.54 & 2.05 & 1.67 \\
\hline B1 & $44-75$ & 276.7 & 95.2 & 259.5 & 0.53 & 7.02 & 1.81 & 1.47 \\
\hline B2 & $75-124$ & 301.4 & 95.1 & 260.7 & 0.47 & 6.52 & 1.97 & 1.59 \\
\hline B3 & $124-170+$ & 305.4 & 94.9 & 254.6 & 0.37 & 5.89 & 2.04 & 1.65 \\
\hline
\end{tabular}


Figure 2 - Representation of the distribution of nodules divided by size class (C1, C2, C3, C4, and C5) in profiles P1, P2, P3, $\mathrm{P} 4$ and P5

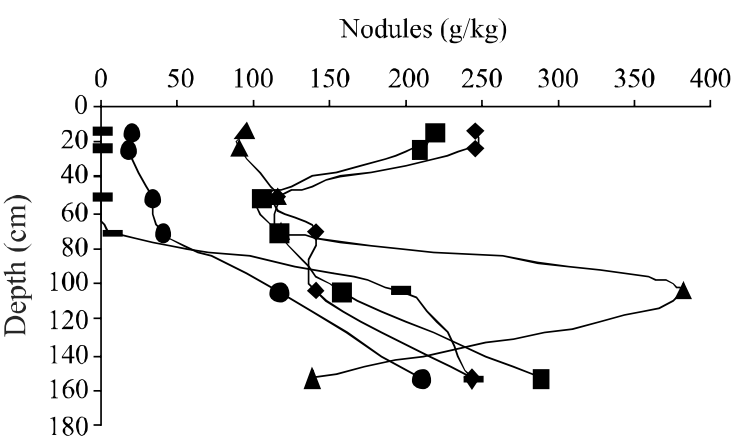

P1 - RED-YELLOW ARGISOL Abrupt eutrophic plintosal (PVAe)

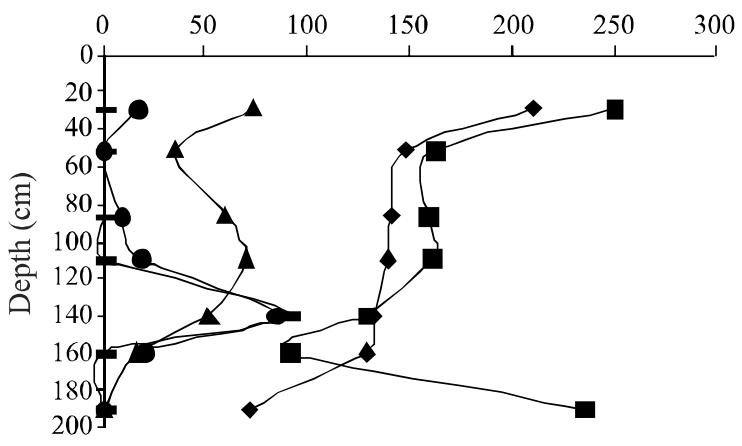

P3 - RED-YELLOW ARGISOL Abrupt eutrophic plintosal (PVAe)

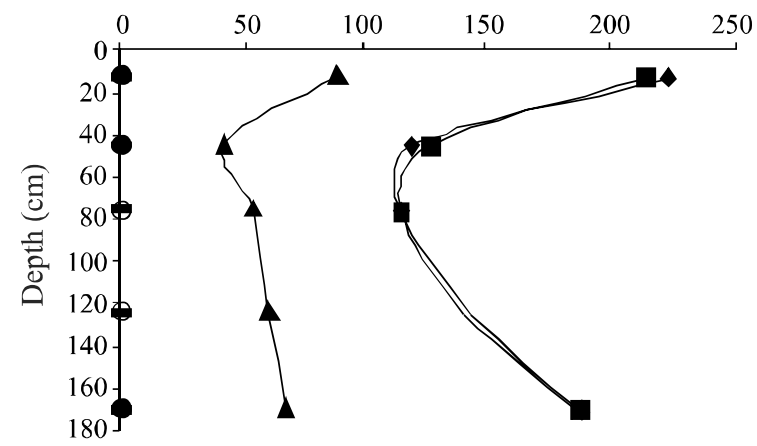

P5 - RED ARGISOL Eutrophic nitosol (PVe)

Yaalon (2009) reports that nodules of different sizes, quantities, hardness and distribution are common in soils developed on carbonate rocks and in an arid climate. Jiménez-Millán and Nieto (2008), studying concretions of iron-manganese in carbonate formations in southeastern Spain, report that these concretions are not only common, but strongly related to differences in facies in the source material, which even in the same rock presents small chemical and structural differences.
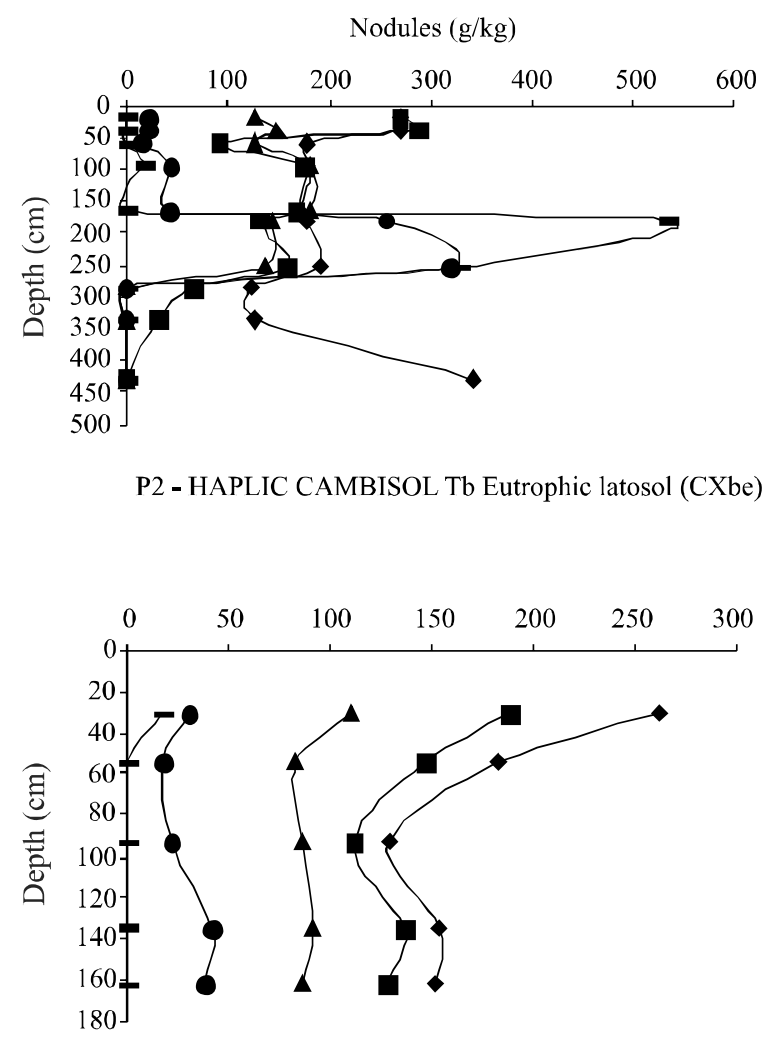

P4 - HAPLIC CAMBISOL Tb Eutrophic latosol (CXbe)

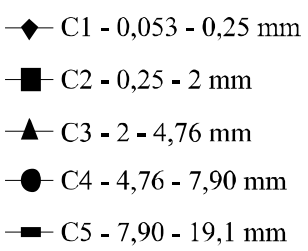

Average values for density were around $2.6 \mathrm{Mg} \mathrm{m}^{-3}$ and similar to those found by Singh and Gilkes (1996). It can also be seen that nodule density is greater on the surface, becoming smaller with depth (Figure 3). The increase in density takes place with a decrease in diameter. This inverse relationship between the size and density of the concretions is related to incorporation of the soil matrix, mainly quartz and kaolinite, during the formation and development 
Figure 3 - Representation of the average density of nodules divided by class (C1, C2, C3, C4, and C5) in profiles P1, P2, P3, P4 and P5

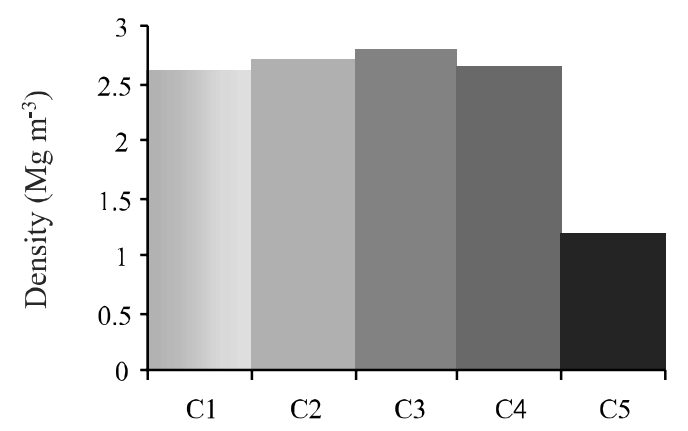

P1 - RED-YELLOW ARGISOL

Abrupt eutrophic plintosal (PVAe)

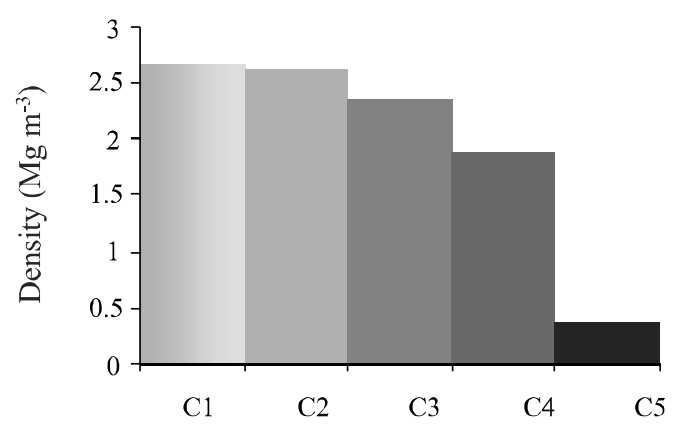

P3 - RED-YELLOW ARGISOL

Abrupt eutrophic plintosal (PVAe)

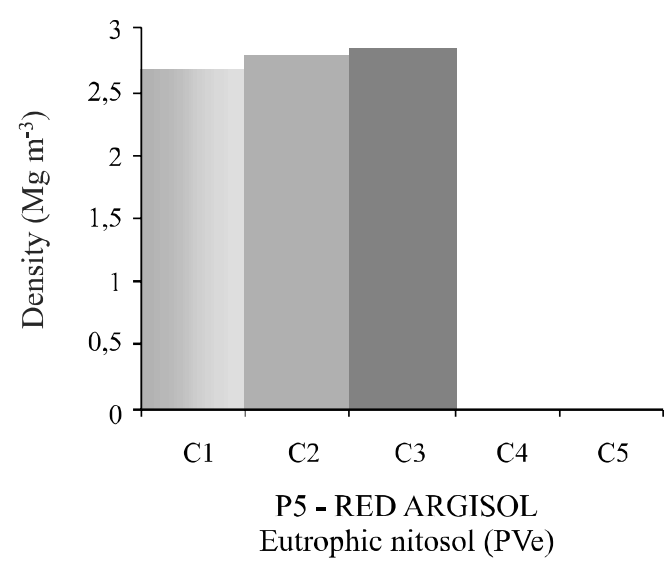

of the nodules increasing the pore space, thereby resulting in a lower density.

In profiles $\mathrm{P} 1, \mathrm{P} 2$ and $\mathrm{P} 3$, high proportions of rounded-habit nodules were seen in the gravel fraction (classes C3, C4 and C5), which displayed a low mechanical resistance. However, nodules with smaller diameters, belonging to the sand fraction, were mechanically resistant, resembling lead shot.

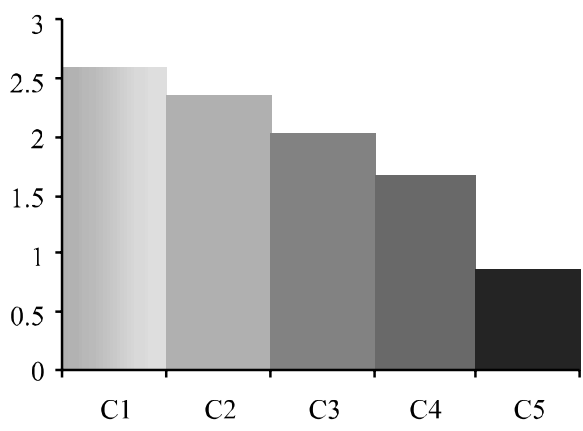

P2 - HAPLIC CAMBISOL

$\mathrm{Tb}$ Eutrophic latosol (Xbe)

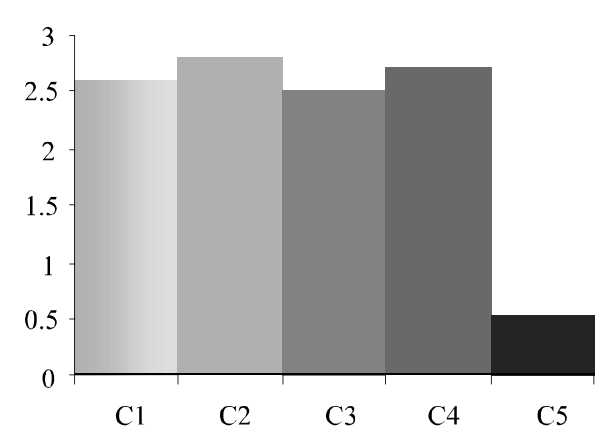

P4 - HAPLIC CAMBISOL

$\mathrm{Tb}$ Eutrophic latosol (Xbe)

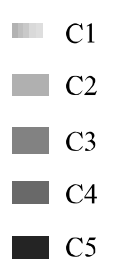

Given the conditions for development of the limestone that makes up the Jandaíra Formation, such as shallow-water marine environments, the formation of rounded limestone structures is common and often associated with ferrous compounds (CASSAB, 2003). Also characteristic of this environment is a rise in water temperature, favouring the precipitation of carbonates, mainly $\mathrm{Ca}$ and $\mathrm{Fe}$, while the movement of the waves may have rounded the bodies that were formed. 
Analysing the levels of $\mathrm{Fe}_{\mathrm{d}}$ in the nodules of profiles P2 and P4, classified as Cambisols (Figure 4), values increase with diameter for classes $\mathrm{C} 1, \mathrm{C} 2$ and $\mathrm{C} 3$, suggesting greater variation in the degree of crystallinity. Whereas for profiles P3 and P5, classified as Argisols, there is greater homogeneity, especially in the last profile which has characteristics related to more evolved soil.

In profile P5 the horizons displayed a homogeneous distribution for nodule mass and density, a fact which demonstrates progress of the weathering processes, a slight increase can also be seen in the quantity of nodules of classes $\mathrm{C} 1, \mathrm{C} 2$ and $\mathrm{C} 3$ on the surface, which may be related to an environmental condition which favours their preservation, since in this horizon conditions of hydromorphism are virtually absent when compared to the subsurface layers.
Also in profile P5 no nodules of classes $\mathrm{C} 4$ and $\mathrm{C} 5$ were recorded (Figure 2), which confirms that, both in the horizons and in the more advanced profiles, there is a reduction in larger-diameter iron nodules, suggesting their degradation with the advancement of the weathering process.

From the observations made here, a significant relationship can be seen between the processes of oxidation/reduction in the dissolution of limestone material, and consequently a change in the dynamics of the iron accumulating in the form of nodules in horizons of currently oxidic conditions. In this study, the number of nodules identified and their characteristics are not seen as limiting the development of agricultural activities; a fact which is relevant faced with the economic importance of this region, however genetic peculiarities in the nodules should be pointed out which are giving rise to more extensive approaches.

Figure 4 - Average values for iron in the sodium dithionite-citrate-bicarbonate $\left(\mathrm{Fe}_{\mathrm{d}}\right)$ and iron in the ammonium oxalate $\left(\mathrm{Fe}_{\mathrm{o}}\right)$ for classes C1, C2, C3, C4 and C5 of profiles P1, P2, P3, P4 and P5
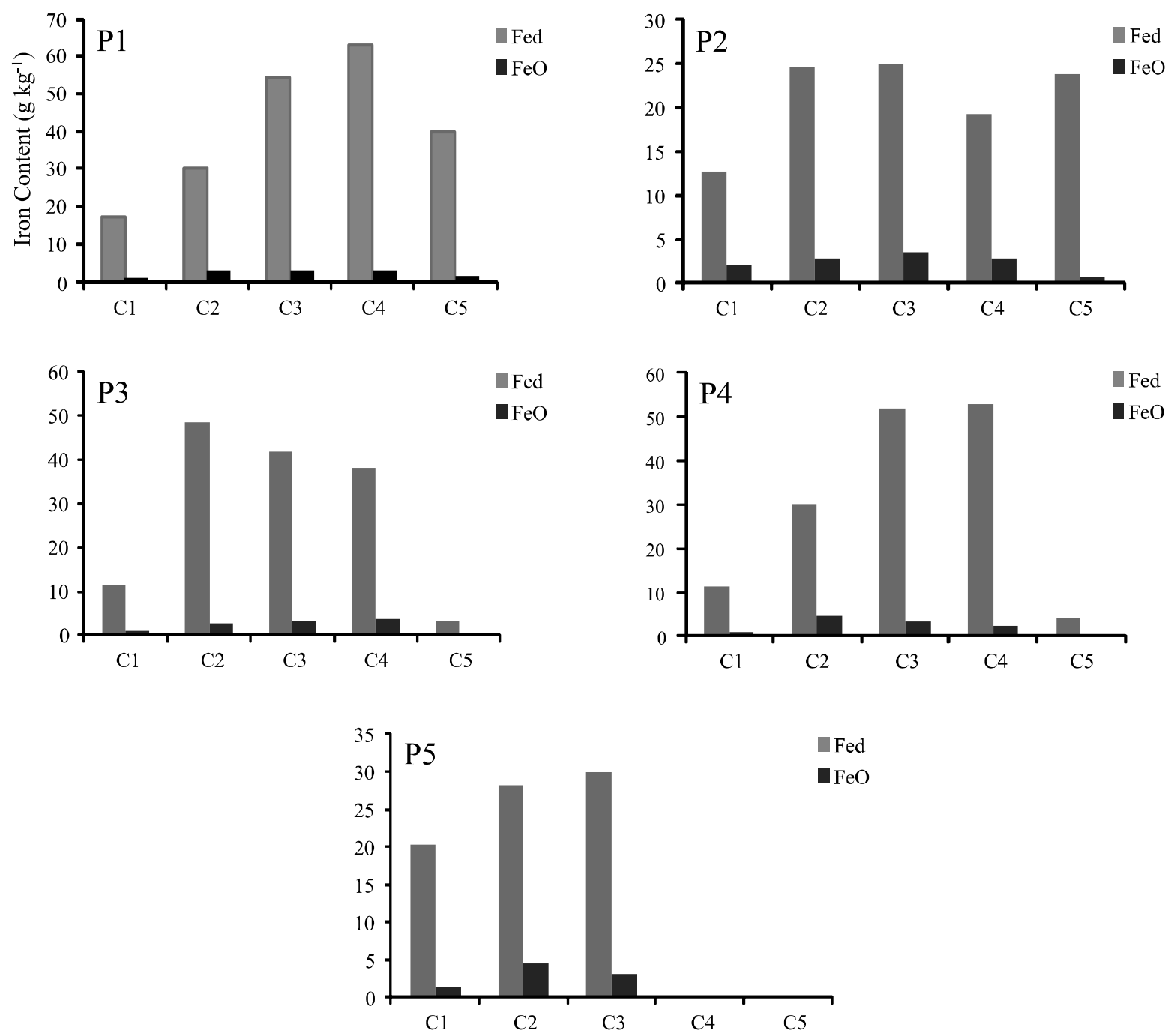


\section{CONCLUSIONS}

1. The influence of the factors of formation on the process of genesis has the source material as a factor of determining importance; with the soils presenting variations in morphological, chemical and physical data, indicating a change in the characteristics of the source material, with emphasis on variations in the amounts of iron and titanium;

2. The reduction in the amount and diameter of the iron nodules in the more evolved horizons and profiles is evidence that such nodules are in the process of degradation, influenced by the advanced weathering process.

\section{REFERENCES}

ACHURRA, L. E. et al. Manganese nodules in the Miocene Bahía Inglesa Formation, north-central Chile: Petrography, geochemistry, genesis and palaeoceanographic significance. Sedimentary geology, v. 217, n. 1, p. 128-139, 2009.

ALENCAR, E. L. L. Química e mineralogia de três pédons originários de calcário da Chapada do Apodi-CE. 2002. 83 f. Dissertação (Mestrado em Solos e Nutrição de Plantas) - Universidade Federal do Ceará, Fortaleza, 2002.

ANJOS, L. H. C. et al. Caracterização e classificação de plintossolos no município de Pinheiro-MA. Revista Brasileira de Ciências do Solo, v. 31, n. 5, p. 1035-1044, 2007.

AROCENA, J. M.; PAWLUK, S.; DUDAS, M. J. Iron oxides in iron rich nodules of sandy soils from Alberta (Canada). In: RINGROSE-VOASE, A. J.; HUMPHREYS, G. S. (Ed.), Soil Micromorphology: Studies in Management and Genesis. Elsevier, 1994. p. 83-97.

AYDINALP, C.; FITZPATRICK, E. A. Pedogenesis and characteristics of the Terra Rossas developed on different physiographic position and their classification. Agrociencia, v. 43, n. 2, p. $97-105,2009$.

BAUTISTA, F. et al. Spatial distribution and development of soils in tropical karst areas from the Peninsula of Yucatan, Mexico. Geomorphology, v. 135, n. 3/4, p. 308321, 2011.

BRASIL. MINISTÉRIODAAGRICULTURA. Levantamento Exploratório-Reconhecimento de solos do estado do Ceará. Recife, 1973. 297 p. v. 1.

BRASIL. MINISTÉRIO DAS MINAS E ENERGIA. SECRETARIA GERAL. Projeto RADAMBRASIL. Folhas SB. 24/25 Jaguaribe/Natal; geologia, geomorfologia, pedologia, vegetação e uso potencial da terra. Rio de Janeiro, 1981. 774 p. v. 23.

CASSAB, R. C. T. Paleontologia da Formação Jandaíra, cretáceo superior da bacia potiguar, com ênfase na paleobiologia dos gastrópodos. 2003. 184 f. Tese (Doutorado em Geologia) Universidade Federal do Rio de Janeiro, Rio de Janeiro.

COELHO, M. R.; VIDAL-TORRADO, P. Caracterização e gênese de perfis plínticos desenvolvidos de arenito do grupo Bauru. II - Mineralogia. Revista Brasileira de Ciência do Solo, v. 27, n. 3, p. 495-507, 2003.

CONSTANTINI, E. A. C. et al. Using the analysis of iron and iron oxides in paleosols (TEM, geochemistry and iron forms) for the assessment of present and past pedogenesis. Quaternary International, v. 156/157, p. 200-211, 2006.

CONSTANTINI, E.A. C.; PRIORI, S. Pedogenesis of plinthite during early Pliocene in the Mediterranean environment: Case study of a buried paleosol at Podere Reniere, central Italy. Catena, v. 71, n. 3, p. 425-443, 2007.

DELGADO, R. et al. Genesis of the terrae rossae of the Sierra Gádor (Andalusia, Spain). European Journal of Soil Science, v. 54, n. 1, p. 1-16, 2003.

EMPRESABRASILEIRADEPESQUISAAGROPECUÁRIA. Centro Nacional de Pesquisa de solos Manual de métodos de análise de solo. 2. Ed. Rio de Janeiro: Embrapa Solos, 1997. $212 \mathrm{p}$.

EMPRESA BRASILEIRA DE PESQUISA AGROPECUÁRIA. Centro Nacional de Pesquisa de solos 2013. Sistema Brasileiro de Classificação de Solos. 3. ed. Brasília, 2013. 353 p.

FENG, J. L. Trace elements in ferromanganese concretions, gibbsite spots, and the surrounding terra rossa overlying dolomite: Their mobilization, redistribution and fractionation. Journal of Geochemical Exploration, v. 108, n. 1, p. 99$111,2011$.

FOSTER, J.; ChITTleborough, D. J.; BAROVICH, K. Genesis of a Terra Rossa soil over marble and the influence of a neighbouring texture contrast soil at Delamere, South Australia. 2004. Australia. In: AUSTRALIAN NEW ZEALAND SOILS CONFERENCE, Australia: University of Sydney, Australia, 2004. p. 5-9. 1 CD-ROM.

HUANG, L. et al. Characteristics of micromorphology and element distribution of iron-manganese cutans in typical soils of subtropical China. Geoderma, v. 146, n. 1/2, p. 4047, 2008.

INDA JUNIOR, A. V.; KÄMPF, N. Avaliação de procedimentos de extração dos óxidos de ferro pedogênicos com ditionitocitrato-bicarbonato de sódio. Revista Brasileira de Ciências do Solo, v. 27, n. 6, p. 1139-1147, 2003.

INDA JUNIOR, A. V.; KÄMPF, N. Variabilidade de goethita e hematita via dissolução redutiva em solos de região tropical e subtropical. Revista Brasileira de Ciências do Solo, v. 29, n. 6, p. 851-866, 2005.

JIMÉNEZ-MILLÁN, J.; NIETO, L. M. Geochemical and mineralogical evidence of tectonic and sedimentary factors controlling the origin of ferromanganese crusts associated to stratigraphic discontinuities (Betic Cordilleras, SE of Spain). Chemie der Erde - Geochemical, v. 68, n. 3, p. 323-336, 2008. 
KHORMALI, F. et al. Argillic horizon development in calcareous soils of arid and semiarid regions of southern Iran. Catena, v. 53, n. 3, p. 273-301, 2003.

LYNCH, L. S. Gênese e geoquímica de solos em ambiente cárstico no cerrado na região de Planaltina de Goiás. 2009. 155 f. Tese (Doutorado em Solos e Nutrição de Plantas) Universidade Federal de Viçosa, Viçosa, 2009.

MEHRA, O. P.; JACKSON, M. L. Iron oxide removal from soils and clays by a dithionite-citrate system buffered with sodium bicarbonate. Clay Clay Mineralogy, v. 72, p. 317-327, 1960.

MOTA, J. C. A. et al. Atributos mineralógicos de três solos explorados com a cultura do melão na chapada do Apodi-RN. Revista Brasileira de Ciências do Solo, v. 31, n. 3, p. 445454, 2007.

MOTA, J. C. A. et al. Algumas propriedades físicas e hídricas de três solos na chapada do Apodi, RN, cultivados com melão. Revista Brasileira de Ciências do Solo, v. 32, n. 1, p. 49-58, 2008.

OLIVEIRA, C. V. et al. Atributos micromorfológicos de solos do projeto Jaíba, norte de Minas gerais. Revista Brasileira de Ciências do Solo, v. 24, n. 1, p. 117-128, 2000.

PEREIRA, M. G. et. al. Caracterização e classificação de solos em uma topossequência sobre calcário na serra da bodoquena, MS. Revista Brasileira de Ciências do Solo, v. 37 , n. 1, p. 25-36, 2013.

SANTOS, R. D et al. Manual de descrição e coleta de solo no campo. 5. ed. Viçosa: Sociedade Brasileira de Ciência do Solo, 2005. 100 p.
SILVA, M. B. et al. Gênese e classificação dos solos de uma topossequência em área de carste na Serra da Bodoquena, MS. Revista Brasileira de Ciências do Solo, v. 37, n. 1, p. 14641480,2013

SILVA NETO, L. F. Óxidos de ferro em latossolos tropicais e subtropicais brasileiros em plantio direto. Revista Brasileira de Ciências do Solo, v. 32, p. n. 5, 1873-1881, 2008.

SINGH, B.; GILKES, R. J. Nature and properties of iron rich glaebules and mottles from some south-west Australian soils. Geoderma, v. 71, n. 1/2, p. 95-120, 1996.

TAN, W. et al. Elemental composition and geochemical characteristics of Iron-Manganese nodules in main soils of China. Pedosphere, v. 16, n. 1, p. 72-81, 2006.

TARDY, Y.; NAHON, D. B. Geochemistry of laterites. Stability of Al-goethite, Al-hemathite end $\mathrm{Fe}^{3+}$-kaolinite in bauxites and ferricretes. An approach to the mechanism of concretion formation. American Journal of Science, v. 285, p. 865-903, 1985.

URLEY, A. L.; DREES, L. R. Methods of Soil Analysis. Soil Science Society of America. Madison, 2008. 521 p.

YAALON, D. H. Brief comments on red Mediterranean soils. Catena, v. 76, n. 3, p. 224, 2009.

YEOMANS, J. C.; BREMNER, J. M. A rapid and precise method for routine determimation of organic carbon in soil. Communication in Soil Science Plant Analysis, v. 19, n. 13, p.1467-1476, 1988. 